\section{Bell Pepper (Capsicum annum L.) Grown on Plastic Film Mulches: Effects on Crop Microenvironment, Physiological Attributes, and Fruit Yield}

\author{
Juan Carlos Díaz-Pérez ${ }^{1}$ \\ Department of Horticulture, Tifton Campus, University of Georgia, 4604 \\ Research Way, Tifton, GA 31793-0748
}

Additional index words. plasticulture, plastic mulch, root zone temperature, heat stress, soil temperature, $P A R$, Tomato spotted wilt, thrips, plant biomass, mineral nutrition, fruit yield

\begin{abstract}
Plastic mulches are widely used for the production of vegetables. There are numerous studies on the use of plastic mulches for peppers, although relatively few have focused on the microenvironmental and physiological impacts of plastic mulches on bell pepper. The objectives were to determine the effects of plastic film mulches on root zone temperature (RZT), soil water status, incidence of thrips and Tomato spotted wilt (TSW), plant growth, gas exchange, accumulation of mineral nutrients, and fruit yield in bell pepper. The study was conducted in Tifton, GA, in the Fall of 2002 and the Spring of 2003 using eight colored plastic mulches. Plastic mulch color influenced the microenvironmental, physiological, and yield responses of bell pepper plants. Plastic film mulches differed in their soil-warming ability with RZTs in both spring and fall being highest in black mulches and lowest in silver mulches. The percentage of photosynthetically active radiation $(P A R)$ reflected from the mulches was highest in silver mulches and lowest in black mulches. The mean RZT under the plastic mulch decreased with increasing percentages of reflected $P A R$. The number of thrips per flower and the incidence of TSW in mature plants were not significantly different among plastic mulch treatments. The number of thrips per flower had no relationship with the percentage of reflected $P A R$ or with RZT. Plastic mulch treatments had no significant effect on soil water status. Neither soil water content nor soil water potential had a relationship with RZT. In the fall season, during the first $\mathbf{2 8}$ days after transplanting, plant growth attributes were among the highest in silver mulches and the lowest in black mulches. Gas exchange and accumulation of mineral nutrients in the leaves and the fruit were not significantly affected by plastic mulches. Both marketable and total yields were higher on silver mulches and lowest on black mulch in the fall, whereas they were in general higher on silver with a black strip mulch and lowest on white and silver1 mulches in the spring. The reduced plant growth and fruit yields in black mulches during the fall were probably the result of the increased RZTs, and thus higher heat accumulation, that resulted in higher plant heat stress conditions compared with silver and white mulches. Fruit yield decreased with mean seasonal RZTs above $27.5^{\circ} \mathrm{C}$. The optimal range of RZT for bell pepper fruit yield was computed to be 25 to $27.5^{\circ} \mathrm{C}$ or less.
\end{abstract}

\footnotetext{
Received for publication 30 Mar. 2010. Accepted for publication 29 June 2010.

I am graciously thankful to Denne Bertrand and David Giddens for invaluable technical support. Thanks also to G. Acuña for help with field and laboratory tasks. I appreciate the kind suggestions of Dr. Dharma Pitchay and the review of the manuscript by Drs. George Boyhan and Patrick Conner and the anonymous reviewers. I also acknowledge the support of the following donors: United Irrigation and Roberts Irrigation Products Inc. for drip tape; Lewis Taylor Farms (Ty Ty, GA) for the bell pepper transplants; Hydro Agri North America, Inc. for calcium nitrate liquid fertilizer; and ReflecTek Foils, Inc. for plastic film mulches. Mention of trade names in this publication does not imply endorsement by the University of Georgia of products named nor criticism of similar ones not mentioned.

${ }^{1}$ Associate Professor.

e-mailjcdiaz@uga.edu.
}

Pepper (Capsicum annum L.) is a solanaceous crop that originated in Mesoamerica (Mexico and Central America) and South America and is now cultivated all over the world (Bosland, 1992). The fruit is highly appreciated for its flavor and high content of provitamin A and ascorbic acid (Rubatzky and Yamaguchi, 1999). There is currently in the United States an increasing demand for peppers, particularly by the rapidly growing Latino population. Pepper is a warm-season crop sensitive to low temperatures and frosts. It is cultivated in altitudes that range from sea level to $3000 \mathrm{~m}$ above sea level. The optimal temperature range for pepper is 20 to $25^{\circ} \mathrm{C}$ (Rubatzky and Yamaguchi, 1999; Wien, 1997).

In many regions of the world, over the last 20 years, vegetable production has shown significant yield increases [Krug, 1999; U.S.
Department of Agriculture (USDA), 2007]. Plasticulture techniques such as plastic film mulch and drip irrigation have undoubtedly contributed considerably to these increases in production (Lamont, 1993). The benefits from the use of plastic mulches include earlier and higher yields, reduced weed populations, reduced soil evaporation, reduced fertilizer leaching, greater water use efficiency, reduced soil compaction, control of certain pests, and a cleaner harvested product (Lamont, 1993). However, the effects of plastic mulches on other factors such as plant diseases, soil moisture, and plant uptake and accumulation of mineral nutrients are much less understood.

Despite the large body of literature demonstrating the positive impact of the use of plastic film mulch in vegetables, there is still a limited understanding about the way plastic film mulches modify the crop microenvironment resulting in increased fruit yield and quality of pepper and other crops (Dodd et al., 2000; Gough, 2001; Ibarra-Jimenez et al., 2001; Locascio et al., 1985). Plastic mulches alter the crop microclimate by changing the soil energy balance (Liakatas et al., 1986; Tarara, 2000), resulting in changes in soil temperature that may positively affect plant growth and yield (Cooper, 1973; Díaz-Pérez and Batal, 2002; Ibarra-Jimenez et al., 2006; Lamont, 2005). In warm environments, however, plastic mulches may create high root zone temperature (RZT) conditions that may be deleterious to growth and yield of vegetables (Díaz-Pérez and Batal, 2002; IbarraJimenez et al., 2008; Lamont, 2005). RZT influences physiological processes such as plant growth, gas exchange, and uptake of water and mineral nutrients (Cooper, 1973; Dodd et al., 2000; Tindall et al., 1990).

The objectives were to determine the effects of colored plastic film mulches on root zone temperature, soil water status, number of thrips per flower and incidence of Tomato spotted wilt (TSW), plant growth, gas exchange, accumulation of mineral nutrients, and fruit yield in bell pepper grown in the fall and spring seasons.

\section{Materials and Methods}

The study was conducted at the Horticulture Farm, University of Georgia, Tifton Campus, during Fall of 2002 and Spring of 2003. The soil was a Tifton Sandy Loam (a fine loamy-siliceous, thermic Plinthic Kandiudults) with a $\mathrm{pH}$ of 6.4. The design was a randomized complete block with eight treatments (plastic film mulch) and four replications. The plastic mulches were black ("black"; PlastiTech, Saint-Remi, Québec, Canada), black with a 10 -cm wide silver strip ("black with silver strip"; Intergro, Safety Harbor, FL), silver on black ("silver1"; Clarke, Ag Plastics, Greenwood, VA), silver on black ("silver2"; RepelGro, ReflecTek Foils, Inc., Lake Zurich, IL), silver on black with a $10-\mathrm{cm}$ wide black strip along the central portion of the film ("silver with black strip"; RepelGro, Reflectek), white 
("white1"; PlastiTech), white-on-black ("white2"; PlastiTech), and white on black with a silver $10-\mathrm{cm}$ wide silver strip ("white with silver strip"; Intergro). All mulches were made out of low-density polyethylene, $1.52 \mathrm{~m}$ wide, $25 \mu \mathrm{m}$ thick, and their surface texture was slick. Although manufactured by different companies, silver1 and silver2 mulches were visually very similar.

The experimental plot consisted of a 12.2-m long, 0.76- $\mathrm{m}$ wide bed formed on $1.8-\mathrm{m}$ centers. The soil was fumigated with a mixture of 3 methyl bromide: 1 chloropicrin (by weight) at $450 \mathrm{~kg} \cdot \mathrm{ha}^{-1}$. Before laying the mulches with a mulch-laying machine, the soil was fertilized with nitrogen $(\mathrm{N})$, phosphorus $(\mathrm{P})$, and potassium $(\mathrm{K})$ at 90,90 , and $112 \mathrm{~kg} \cdot \mathrm{ha}^{-1}$, respectively. At the same time the mulches were laid, drip irrigation tape (Ro-Drip; Roberts Irrigation Products, Inc., San Marcos, CA), with 20.3-cm emitter spacing and an $8.3 \mathrm{~mL} \cdot \mathrm{min}^{-1}$ emitter flow, was placed $5 \mathrm{~cm}$ deep in the center of the bed.

Six-week-old bell pepper 'Wizard' (Seminis, Oxnard, CA) transplants were planted to the field on 14 Aug. 2002 (Fall) and 18 Apr. 2003 (Spring). Plants were established using two rows per bed $(36 \mathrm{~cm}$ apart) with a distance of $30 \mathrm{~cm}$ between plants within the row. After transplanting, $\approx 240 \mathrm{~mL}$ of starter fertilizer solution (555 ppm N; 821 ppm P; 0 ppm K) was applied directly to the base of each transplant. Three weeks after transplanting, plants were fertilized weekly through the drip system with $\mathrm{N}$ and $\mathrm{K}$ at rates of $1.5 \mathrm{~kg} \cdot \mathrm{ha}^{-1} \cdot \mathrm{d}^{-1}$ at early stages, $2.0 \mathrm{~kg} \cdot \mathrm{ha}^{-1} \cdot \mathrm{d}^{-1}$ during plant and fruit development, and $1.5 \mathrm{~kg} \cdot \mathrm{ha}^{-1} \cdot \mathrm{d}^{-1}$ at late stages of plant development. The total amount for each $\mathrm{N}$ and $\mathrm{K}$ received by the plants after transplanting was 144 and 179 $\mathrm{kg} \cdot \mathrm{ha}^{-1}$, respectively.

Plants were irrigated with an amount of water equivalent to $100 \%$ crop evapotranspiration (ETc). Crop evapotranspiration was calculated by multiplying the reference evapotranspiration (ETo) by the crop factor (dependent on the crop stage of development). Water was applied when cumulative ETc was $1.2 \mathrm{~mm}$, which corresponded to approximately every 2 to $3 \mathrm{~d}$ in mature plants (mean ETo was $\approx 5$ to $6 \mathrm{~mm} /$ day). Weather data (air temperature and ETo) were obtained from a nearby University of Georgia weather station (less than $300 \mathrm{~m}$ ).

Thrips and Tomato spotted wilt. Thrip numbers were determined by collecting five flowers per plot 4 weeks after transplanting (fall season). The number of thrips per flower was determined with a dissecting microscope. Individual plants were monitored visually for TSW symptoms for the entire season (in both spring and fall). The presence of the virus that causes TSW in all symptomatic plants was confirmed by enzyme-linked immunosorbent assay (ELISA) on pepper leaves using a commercially available kit (Agdia Inc., Elkhart, IN). Asymptomatic plants were not subjected to ELISA.

Soil water status. Soil water status was measured as either soil water content (fall) or soil water potential (spring). Soil water content (volumetric) over the season was measured once every 2 to $3 \mathrm{~d}$ (three readings per experimental plot) with a portable time domain reflectometry (TDR) sensor (CS-620; Campbell Scientific, Logan, UT). The two metallic $12-\mathrm{cm}$ rods of the TDR sensor were inserted vertically within the row between two plants.

Soil water potential was measured manually (every 2 to $3 \mathrm{~d}$ ) with granular matrix sensors (Water Mark Soil Moisture Sensor, Model 200SS; Irrometer Co., Riverside, CA) at $10-\mathrm{cm}$ depth within the row in between two plants using one sensor per experimental plot.

Root zone temperature and photosynthetically active radiation. RZT was measured by determining soil temperature midway between the plants at $10 \mathrm{~cm}$ below the mulched soil surface. RZT over the growing season was measured with copper-constantan thermocouples (Model 107; Campbell Scientific) connected to a data logger (CR10X; Campbell Scientific) and an AM416 Relay Multiplexer (Campbell Scientific). The data logger was programmed to record readings every $10 \mathrm{~min}$ and store hourly averages for each plot. Air temperature data were obtained from a University of Georgia weather station located within $300 \mathrm{~m}$ of the plots.

Incoming and reflected photosynthetically active radiation $(P A R)$ was determined with a ceptometer (Sunfleck PAR ceptometer; Delta-T devices) in the fall season. Incoming and reflected $P A R$ was measured at 14 and $21 \mathrm{~d}$ after transplanting (DAT) on

Table 1. Mean seasonal root zone temperature (RZT), reflected photosynthetically active radiation $(P A R)$, and number of thrips per flower in bell pepper grown on colored plastic film mulches, Tifton, GA, Fall of 2002 and Spring of $2003 .^{z}$

\begin{tabular}{lcccc}
\hline & \multicolumn{3}{c}{ Fall 2002 } & Spring 2003 \\
\cline { 2 - 5 } Mulch & $\begin{array}{c}\text { Mean RZT } \\
\left({ }^{\circ} \mathrm{C}\right)^{\mathrm{x}}\end{array}$ & $\begin{array}{c}\text { Reflected } \\
P A R(\%)^{\mathrm{w}}\end{array}$ & No. thrips/flower & $\begin{array}{c}\text { Mean RZ } \\
\left({ }^{\circ} \mathrm{C}\right)\end{array}$ \\
\hline Black & $28.35 \mathrm{a}^{\mathrm{z}}$ & $7.2 \mathrm{e}$ & 6.3 & $28.04 \mathrm{a}$ \\
Black with silver strip & $28.14 \mathrm{~b}$ & $28.5 \mathrm{~cd}$ & 6.7 & $27.72 \mathrm{~b}$ \\
Silver1 & $27.29 \mathrm{~g}$ & $51.4 \mathrm{a}$ & 7.0 & $26.35 \mathrm{~h}$ \\
Silver2 & $27.62 \mathrm{e}$ & $52.7 \mathrm{a}$ & 6.7 & $26.77 \mathrm{e}$ \\
Silver with black strip & $27.38 \mathrm{f}$ & $45.2 \mathrm{~b}$ & 10.0 & $26.53 \mathrm{~g}$ \\
White1 & $27.95 \mathrm{c}$ & $30.7 \mathrm{~cd}$ & 4.7 & $26.93 \mathrm{c}^{\mathrm{z}}$ \\
White2 & $27.81 \mathrm{~d}$ & $26.1 \mathrm{~d}$ & 8.7 & $26.86 \mathrm{~d}$ \\
White with silver strip & $27.93 \mathrm{c}$ & $32.4 \mathrm{c}$ & 4.7 & $26.60 \mathrm{f}$ \\
$P$ & $<0.001$ & $<0.001$ & 0.428 & $<0.001$ \\
\hline
\end{tabular}

${ }^{\mathrm{z}}$ Means followed by the same letter in a column are not significantly different based on Fisher's protected least significant difference test at $95 \%$ confidence.

yPlastic mulches were black ("black"; PlastiTech, Saint-Remi, Québec, Canada), black with a 10-cm wide silver strip ("black with silver strip"; Intergro, Safety Harbor, FL), silver on black ("silver1"; Clarke, Ag Plastics, Greenwood, VA), silver on black ("silver2"; RepelGro; ReflecTek Foils, Inc., Lake Zurich, IL), silver on black with a 10 -cm wide black strip along the central portion of the film ("silver with black strip"; RepelGro, Reflectek), white ("white1"; PlastiTech), white-on-black ("white2"; PlastiTech), and white on black with a silver $10-\mathrm{cm}$ wide silver strip ("white with silver strip"; Intergro). All mulches were made out of low-density polyethylene, $1.52 \mathrm{~m}$ wide, $25 \mu \mathrm{m}$ thick, and their surface texture was slick.

${ }^{x}$ Means of RZT values measured every 10 min during the entire season. Root zone temperature was measured with copper-constantan thermocouples buried $10 \mathrm{~cm}$ deep and placed between two plants within a row

${ }^{\text {w} M e a n s ~ o f ~ v a l u e s ~ m e a s u r e d ~} 14$ and $21 \mathrm{~d}$ after transplanting with a ceptometer (Delta-T devices).

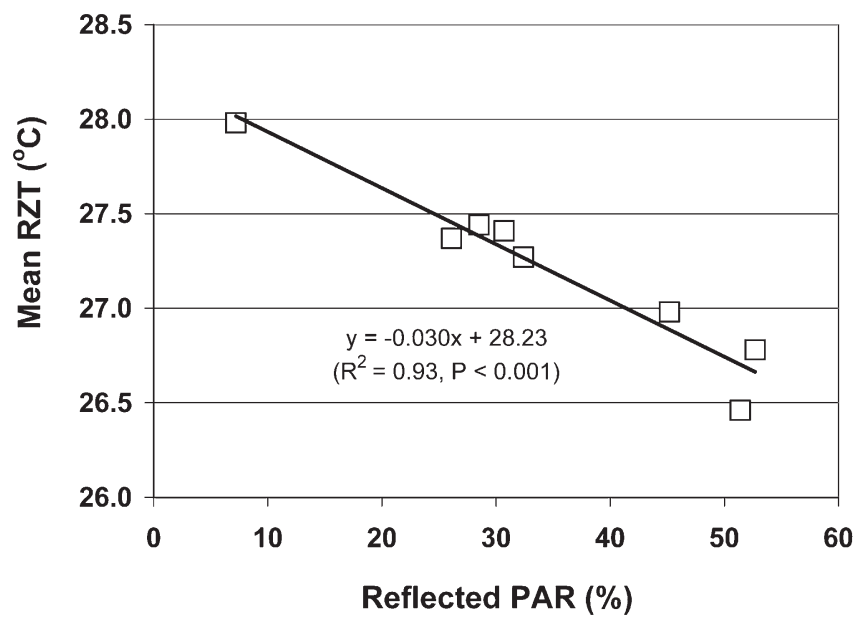

Fig. 1. Mean root zone temperature 14 to $21 \mathrm{~d}$ after transplanting under various colored plastic film mulches as a function of the percentage of reflected photosynthetically active radiation $(P A R)$ from the mulch. Each point represents the mean of four replications. The values of reflected $P A R$ are the mean for measurements taken at midday 14 and $21 \mathrm{~d}$ after transplanting. Root zone temperature was measured every $10 \mathrm{~min}$ with copper-constantan thermocouples $(10 \mathrm{~cm}$ deep) connected to a data logger; Tifton, GA, Fall of 2002. 
clear days at 1300 to $1400 \mathrm{HR}$. Reflected PAR was measured by placing the ceptometer rod in between two rows of plants facing the mulch surface and at $30 \mathrm{~cm}$ above the mulch. Two measurements of each incoming and reflected $P A R$ were taken for each experimental plot. The amount of $P A R$ reflected by the mulches was expressed as a percentage of the incoming PAR.

Gas exchange. Leaf gas exchange measurements (net photosynthesis) were determined with a portable photosynthesis system (LI-6400; LI-COR Inc., Lincoln, NE). Gas exchange measurements were conducted under natural temperature $\left(\right.$ mean $\left.=33.4{ }^{\circ} \mathrm{C}\right)$ and air humidity conditions (mean $17.0 \mathrm{mmol}$ $\mathrm{H}_{2} \mathrm{O} / \mathrm{mol}$ ); $\mathrm{CO}_{2}$ concentration was set at 400 $\mu \mathrm{mol} \cdot \mathrm{mol}^{-1}$ by means of a $\mathrm{CO}_{2}$ mixer and a $\mathrm{CO}_{2}$ tank and $P A R$ at $2000 \mu \mathrm{mol} \cdot \mathrm{m}^{-2} \cdot \mathrm{s}^{-1}$ using a red/blue light source (LI-6400-02B; LI-COR, Inc.). Measurements were conducted in clear days (PAR greater than 1900 $\left.\mu \mathrm{mol} \cdot \mathrm{m}^{-2} \cdot \mathrm{s}^{-1}\right)$, at 1200 to $1400 \mathrm{HR}$ Eastern Standard Time, using three developed and fully exposed leaves per experimental plot. Each measurement lasted $\approx 45$ to $60 \mathrm{~s}$.

Plant growth. On Day 28 after transplanting, two randomly selected vegetative tops (above-ground portion of the plant) from each replication were removed from the soil. Plant tops were dried at $70{ }^{\circ} \mathrm{C}$ and dry weights (DWs) were determined.

Leaf and fruit mineral nutrients. Leaf samples (25 fully developed leaves from new growth) were collected $28,42,56$, and 70 DAT. Fruit samples (five marketable fruit per treatment) were taken from each harvest. Leaf and fruit samples were dried at $70^{\circ} \mathrm{C}$ for $2 \mathrm{~d}$ and analyzed for mineral nutrient concentration. Concentrations of $\mathrm{P}, \mathrm{K}$, calcium, magnesium, iron, manganese, zinc, and copper were determined by atomic absorption spectrophotometry. Tissue $\mathrm{N}$ concentration was determined by the copper catalyst method (AOAC, 1990).

Harvest. For the fall crop, harvests were conducted on 18 and 23 Oct. and 13 Nov., whereas for the spring crop, harvests were on 19 and 30 June. At the last harvest, plants were excised at the soil level, enclosed individually in plastic bags, and kept at $10{ }^{\circ} \mathrm{C}$ until their vegetative fresh weight $(\mathrm{FW})$ and fruit yield (including both developing and fully developed fruit) were determined within $24 \mathrm{~h}$. Fruit were graded as marketable and culls according to the U.S. grade standards (USDA, 2005).

Statistical analysis. Data were analyzed using the Analysis of the Mixed Procedure of SAS (SAS Institute Inc., Cary, NC). Average, maximal, and minimal RZTs for the season were calculated from daily values of mean, maximal, and minimal RZTs for each of the mulches during the entire season. The means for RZT, plant growth attributes, and fruit yields were separated by the Fisher's protected least significant difference test. Relationships of plant growth attributes with RZT were constructed using the means of the interaction of season, mulch, and cultivar. Various models were evaluated to determine whether there were differences in the relationship of plant growth and yield to RZT among seasons and mulch treatments.

\section{Results}

Root zone temperature and reflected photosynthetically active radiation. Fall mean air temperatures $\left[27{ }^{\circ} \mathrm{C}\right.$ (first 42 DAT) and $26.2^{\circ} \mathrm{C}$ (entire season)] and RZTs $\left[28.5^{\circ} \mathrm{C}\right.$ (first $42 \mathrm{DAT}$ ) and $27.8^{\circ} \mathrm{C}$ (entire season)] were higher than spring air temperatures $\left[22.7^{\circ} \mathrm{C}\right.$ (first 42 DAT) and $24.0{ }^{\circ} \mathrm{C}$ (entire season)] and RZTs $\left[25.7^{\circ} \mathrm{C}\right.$ (first 42 DAT) and $27.0{ }^{\circ} \mathrm{C}$ (entire season)]. The values of mean RZT for each season represent a composite for all plastic mulches.

During the growing season, air and RZTs showed a decreasing trend in the fall and an increasing trend in the spring. Plastic film mulches differed in their soil-warming ability with RZTs in both spring and fall seasons being highest in black mulches and lowest in

Table 2. Soil water status of bell pepper crop grown on colored plastic film mulches, Tifton, GA, Fall of 2002 and Spring of $2003 .^{\mathrm{z}}$

\begin{tabular}{lcc}
\hline Mulch $^{\mathrm{y}}$ & Soil water content $^{\mathrm{x}}(\%)$ & Soil water potential $^{\mathrm{w}}(\mathrm{kPa})$ \\
\hline Black & $9.08 \mathrm{~b}$ & $-7.34 \mathrm{~b}$ \\
Black with silver strip & $8.75 \mathrm{bc}$ & $-7.6 \mathrm{~b}$ \\
Silver1 & $9.10 \mathrm{~b}$ & $-7.5 \mathrm{~b}$ \\
Silver2 & $9.52 \mathrm{a}$ & $-4.0 \mathrm{~b}$ \\
Silver with black strip & $8.79 \mathrm{~b}$ & $-6.5 \mathrm{~b}$ \\
White & $8.63 \mathrm{c}$ & $-7.2 \mathrm{~b}$ \\
White2 & $8.79 \mathrm{bc}$ & $-4.9 \mathrm{~b}$ \\
White with silver strip & $8.68 \mathrm{c}$ & $-11.5 \mathrm{a}$ \\
$P$ & 0.018 & $<0.001$ \\
\hline
\end{tabular}

$\overline{{ }^{2} \text { Means followed by the same letter in a column are not significantly different based on Fisher's protected }}$ least significant difference test at $95 \%$ confidence.

yPlastic mulches were black ("black"; PlastiTech, Saint-Remi, Québec, Canada), black with a 10-cm wide silver strip ("black with silver strip"; Intergro, Safety Harbor, FL), silver on black ("silver1"; Clarke, Ag Plastics, Greenwood, VA), silver on black ("silver2"; RepelGro; ReflecTek Foils, Inc., Lake Zurich, IL), silver on black with a 10-cm wide black strip along the central portion of the film ("silver with black strip"; RepelGro, Reflectek), white ("white1"; PlastiTech), white-on-black ("white2"; PlastiTech), and white on black with a silver 10-cm wide silver strip ("white with silver strip"; Intergro). All mulches were made out of low-density polyethylene, $1.52 \mathrm{~m}$ wide, $25 \mu \mathrm{m}$ thick, and their surface texture was slick.

${ }^{x}$ Soil water content was measured every 2 to 3 d during the Fall of 2002 using a portable time domain reflectometry sensor.

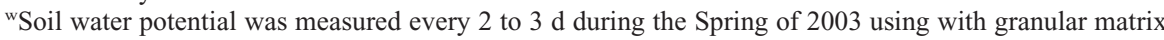
sensors.

Table 3. Growth variables of bell pepper plants grown on colored plastic film mulches $28 \mathrm{~d}$ after transplanting, Tifton, GA, Fall of $2002 .^{\mathrm{z}}$

\begin{tabular}{lcccccc}
\hline Mulch $^{y}$ & $\begin{array}{c}\text { Plant ht } \\
(\mathrm{cm})\end{array}$ & $\begin{array}{c}\text { Stem diam } \\
(\mathrm{mm})\end{array}$ & $\begin{array}{c}\text { Leaf dry wt } \\
(\mathrm{g} / \mathrm{plant})\end{array}$ & $\begin{array}{c}\text { Stem dry wt } \\
(\mathrm{g} / \mathrm{plant})\end{array}$ & $\begin{array}{c}\text { Top dry wt } \\
(\mathrm{g} / \mathrm{plant})\end{array}$ & $\begin{array}{c}\text { Leaf area } \\
\left(\mathrm{cm}^{2} / \mathrm{plant}\right)\end{array}$ \\
\hline Black & $20.4 \mathrm{~b}$ & $4.7 \mathrm{f}$ & $1.8 \mathrm{e}$ & $0.6 \mathrm{~d}$ & $2.5 \mathrm{e}$ & $354 \mathrm{e}$ \\
Black with silver strip & $22.8 \mathrm{ab}$ & $5.7 \mathrm{def}$ & $3.8 \mathrm{cde}$ & $1.1 \mathrm{bcd}$ & $4.9 \mathrm{cde}$ & $739 \mathrm{cde}$ \\
Silver1 & $24.4 \mathrm{a}$ & $8.0 \mathrm{a}$ & $7.5 \mathrm{a}$ & $2.2 \mathrm{a}$ & $9.7 \mathrm{a}$ & $1494 \mathrm{a}$ \\
Silver2 & $24.3 \mathrm{a}$ & $7.9 \mathrm{ab}$ & $6.8 \mathrm{ab}$ & $2.0 \mathrm{ab}$ & $8.8 \mathrm{ab}$ & $1352 \mathrm{ab}$ \\
Silver with black strip & $24.1 \mathrm{a}$ & $6.9 \mathrm{abc}$ & $5.6 \mathrm{abc}$ & $1.8 \mathrm{abc}$ & $7.4 \mathrm{abc}$ & $1107 \mathrm{abc}$ \\
White1 & $20.1 \mathrm{~b}$ & $5.5 \mathrm{ef}$ & $3.3 \mathrm{de}$ & $1.0 \mathrm{~cd}$ & $4.4 \mathrm{de}$ & $656 \mathrm{de}$ \\
White2 & $22.2 \mathrm{ab}$ & $6.2 \mathrm{cde}$ & $5.4 \mathrm{bcd}$ & $1.6 \mathrm{abc}$ & $7.0 \mathrm{abcd}$ & $1064 \mathrm{bcd}$ \\
White with silver strip & $22.6 \mathrm{ab}$ & $6.8 \mathrm{bcd}$ & $5.0 \mathrm{bcd}$ & $1.4 \mathrm{abcd}$ & $6.4 \mathrm{bcd}$ & $990 \mathrm{bcd}$ \\
$P$ & 0.018 & $<0.001$ & $<0.001$ & 0.042 & 0.002 & $<0.001$ \\
\hline
\end{tabular}

${ }^{\mathrm{z}}$ Means followed by the same letter in a column are not significantly different based on Fisher's protected least significant difference test at $95 \%$ confidence.

yPlastic mulches were black ("black"; PlastiTech, Saint-Remi, Québec, Canada), black with a 10-cm wide silver strip ("black with silver strip"; Intergro, Safety Harbor, FL), silver on black ("silver1"; Clarke, Ag Plastics, Greenwood, VA), silver on black ("silver2"; RepelGro; ReflecTek Foils, Inc., Lake Zurich, IL), silver on black with a 10-cm wide black strip along the central portion of the film ("silver with black strip"; RepelGro, Reflectek), white ("white1"; PlastiTech), white-on-black ("white2"; PlastiTech), and white on black with a silver 10-cm wide silver strip ("white with silver strip"; Intergro). All mulches were made out of low-density polyethylene, $1.52 \mathrm{~m}$ wide, $25 \mu \mathrm{m}$ thick, and their surface texture was slick. 
significantly affected by plastic mulch treatment (Table 1). The number of thrips per flower had no relationship with the percentage of PAR reflected from the mulches $\left(r^{2}=\right.$ $0.059)$ or with RZT $\left(r^{2}=0.251\right)$. In both seasons, the incidence of TSW in mature plants was not significantly different among plastic mulch treatments. The mean incidences were $54 \%$ and $2 \%$ in the fall and spring, respectively. The incidence of TSW was not related to the number of thrips per flower.

Soil water status. Silver2 mulch had the highest values of soil water content (fall) and soil water potential (spring) among plastic mulches (Table 2). However, there were not consistent values of soil water content and soil water potential associated with mulch color. Neither soil water content nor soil water potential had a relationship with RZT.

Plant growth. In the fall, growth attributes during the first 28 DAT were among the highest in silver mulches and the lowest in black mulches (Table 3). Top DW, leaf DW, stem DW, and stem diameter decreased with increasing values of mean RZT during the first 28 DAT (Fig. 2). Plant height also decreased with increasing RZTs $\left(R^{2}=\right.$ 0.695; $P=0.051$ ).

Stem diameter was highly related to leaf DW $\left(R^{2}=0.951 ; P<0.0001\right)$, stem DW $\left(R^{2}=\right.$ $0.925 ; P<0.0001)$, and top DW $\left(R^{2}=0.947\right.$; $P<0.0001)$. Top DW was more related to stem diameter than to plant height $\left(R^{2}=\right.$ 0.776; $P=0.004$ ). Bell pepper plant growth during plant establishment had a large effect on subsequent plant growth and fruit yield. Both final vegetative top FW and total fruit yield increased with increasing top DW during the first 28 DAT (Fig. 3). Final vegetative top FW did not respond to changes in RZT among mulches in the spring but declined quadratically with increasing RZTs in the fall $\left(R^{2}=0.80 ; P=0.017\right)$.

Gas exchange. There were few differences in net photosynthesis $\left(\mathrm{P}_{\mathrm{n}}\right)$ resulting from plastic mulches. In the fall, 28 DAT, $\mathrm{P}_{\mathrm{n}}$ was highest in silver mulch with a black strip $\left(25.0 \mu \mathrm{mol} \cdot \mathrm{m}^{-2} \cdot \mathrm{s}^{-1}\right)$ and lowest in silver1 $\left(21.7 \mu \mathrm{mol} \cdot \mathrm{m}^{-2} \cdot \mathrm{s}^{-1}\right)$, whereas it was intermediate for the other plastic mulches. In the spring, $P_{n}$ was similar among mulch treatments 40 DAT $\left(\right.$ mean $=26.2 \mu \mathrm{mol} \cdot \mathrm{m}^{-2} \cdot \mathrm{s}^{-1}$ ) and 43 DAT $\left(\right.$ mean $\left.=27.3 \mu \mathrm{mol} \cdot \mathrm{m}^{-2} \cdot \mathrm{s}^{-1}\right)$. There was no relationship between $\mathrm{P}_{\mathrm{n}}$ and RZT.

Leaf and fruit mineral nutrients. Leaf and fruit mineral nutrient concentrations showed no response to mulch in the fall (Tables 4 and 5 ), whereas in the spring, some nutrients varied among mulch treatments (Tables 6 and 7). The concentrations of the majority of nutrients (except calcium and manganese) declined as the season progressed in both fall and spring. Leaf nutrient concentrations 28 DAT in the fall were not related with the mean RZT (daily mean from planting to 28 DAT) or with growth attributes. The foliar concentrations of $\mathrm{N}, \mathrm{P}, \mathrm{K}$, calcium, and magnesium in mature plants were not correlated with their corresponding fruit concentrations.
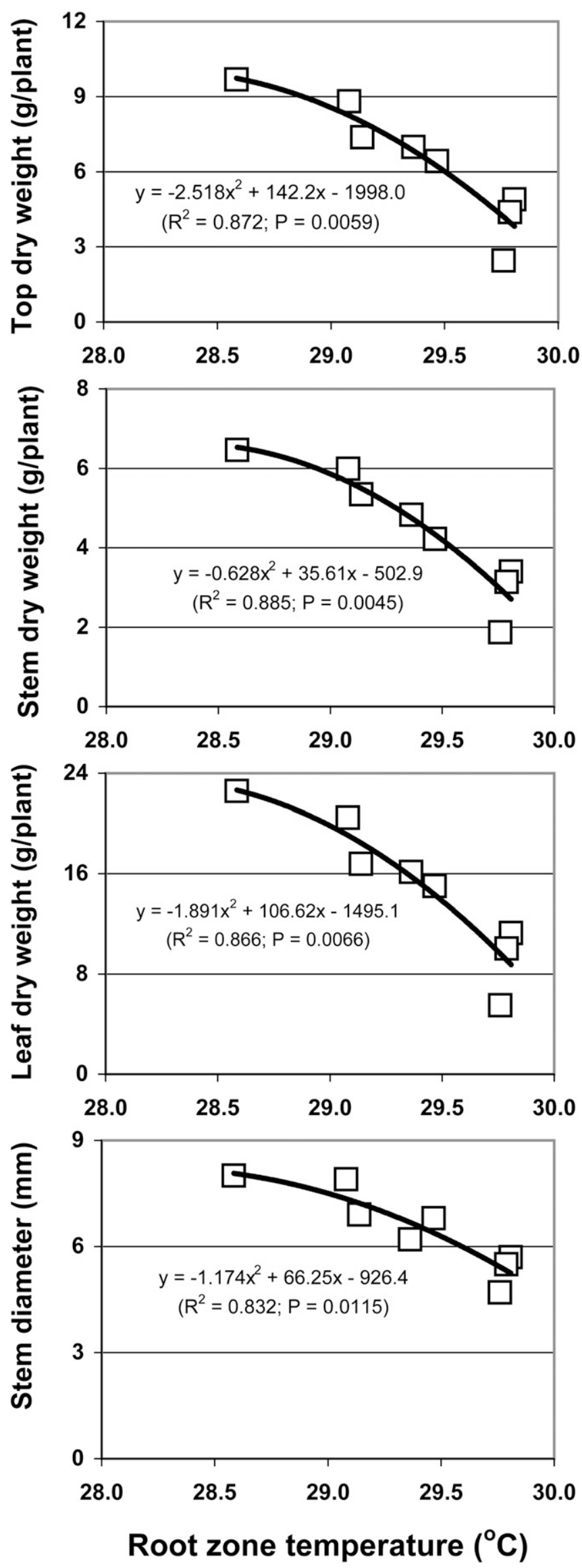

Fig. 2. Top dry weight, stem dry weight, leaf dry weight, and stem diameter of bell pepper plants $28 \mathrm{~d}$ after transplanting as a function of the mean root zone temperature under plastic film mulch of various colors during the first $28 \mathrm{~d}$ after transplanting. Each point represents the mean of four replications for each plastic mulch treatment; Tifton, GA, Fall of 2002. 

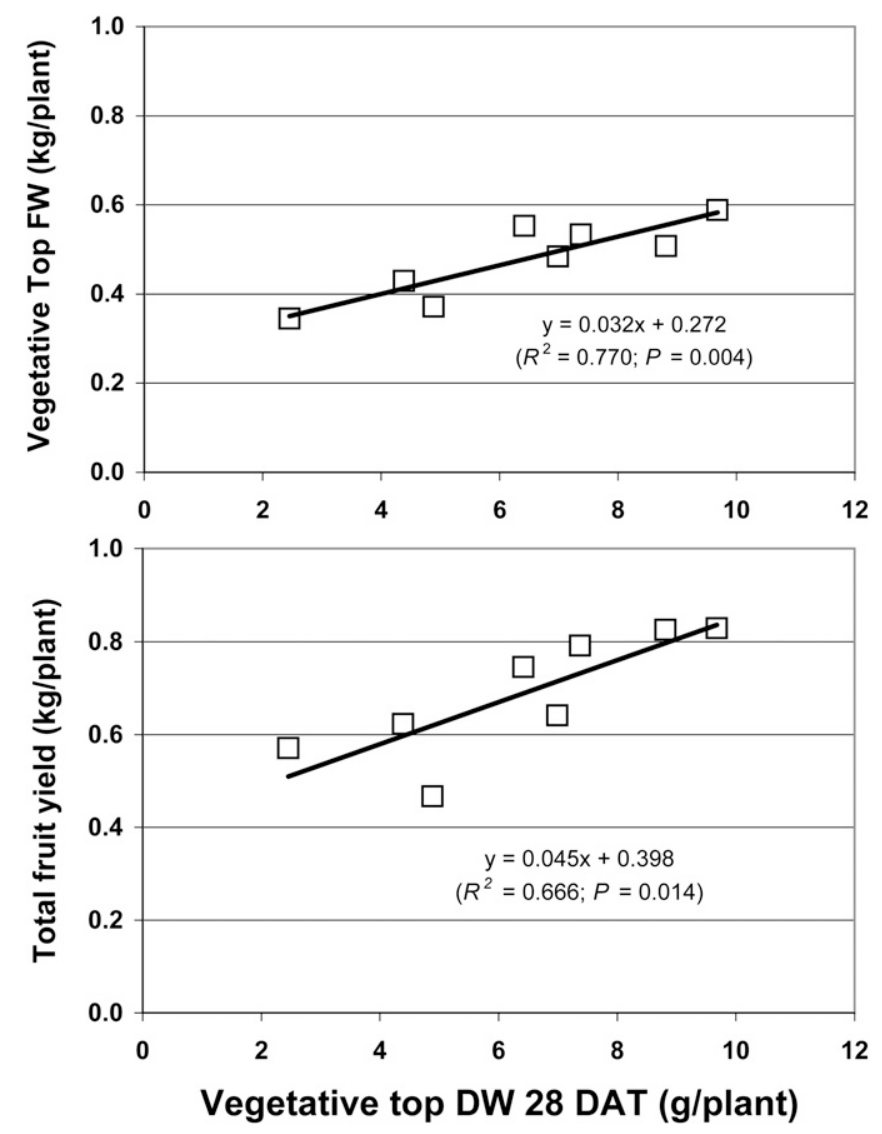

Fig. 3. Final vegetative top fresh weight and total fruit yield as a function of the top dry weight of bell pepper plants $28 \mathrm{~d}$ after transplanting. Bell pepper plants were grown on various colored plastic film mulch treatments. Each point represents the mean of four replications for each plastic mulch treatment; Tifton, GA, Fall of 2002.
Fruit yield. Fruit yields in fall and spring seasons are shown in Table 8. In the fall, when soils were warmer, primarily early in the season, both marketable and total yields were higher on silver mulches and lowest on black mulch. In the spring, when soils were cooler early in the season, there were few yield differences among mulch treatments. The range in fruit yield among treatments was $0.36 \mathrm{~kg} /$ plant $(77 \%$ of the mulch treatment with the lowest yield) in the fall and $0.23 \mathrm{~kg} /$ plant $(27 \%$ of the mulch treatment with the lowest yield). In both seasons, the total number of fruit was much larger than the number of marketable fruit because bell pepper plants had a large number of cull fruit, which included immature green fruit as well as fruit with decay and physiological disorders.

The relationships of both fall and spring fruit yield data as a function of mean RZTs for the season and for the first 42 DAT are shown in Figure 4. Fruit yield was little affected below $27{ }^{\circ} \mathrm{C}$ but decreased above $\approx 27{ }^{\circ} \mathrm{C}$. From the quadratic equations in Figures $4 \mathrm{~A}$ and $4 \mathrm{~B}$, optimal RZTs for fruit yield were calculated to be $25.9{ }^{\circ} \mathrm{C}$ (mean RZT for the first $42 \mathrm{DAT}$ ) and $26.3^{\circ} \mathrm{C}$ (mean seasonal RZT). However, curves in Figures $4 \mathrm{~A}$ and $4 \mathrm{~B}$ suggest that the relationships of fruit yield with RZT may be better described by an optimal range in RZT rather than an optimal RZT point value (as derived from the quadratic equations). The optimal ranges were calculated as the range in RZTs in which fruit yield was $90 \%$ or higher compared with the yield at the optimal RZT point value. The RZT data from both trials were not low enough to allow to calculate the lower point of the optimal RZT range, i.e., RZTs

Table 4. Leaf nutrient concentrations in bell pepper as affected by plastic mulch color and days after transplanting. Tifton, GA, Fall of 2002. ${ }^{2}$

\begin{tabular}{|c|c|c|c|c|c|c|c|c|c|}
\hline \multirow{2}{*}{$\operatorname{Mulch}(\mathrm{M})^{\mathrm{y}}$} & \multicolumn{9}{|c|}{ Nutrient concn } \\
\hline & Nitrogen & Phosphorus & Potassium & Calcium & Magnesium & Manganese & Iron & Zinc & Copper \\
\hline Black & 6.4 & 0.76 & 4.4 & 1.2 & 0.7 & 137 & 211 & 187 & 17 \\
\hline Silver1 & 6.2 & 0.66 & 4.2 & 1.0 & 0.7 & 129 & 212 & 161 & 12 \\
\hline Silver2 & 6.3 & 0.72 & 4.0 & 1.0 & 0.6 & 120 & 211 & 180 & 19 \\
\hline Silver with black strip & 6.4 & 0.74 & 4.0 & 1.1 & 0.6 & 123 & 194 & 163 & 14 \\
\hline White 1 & 6.1 & 0.68 & 5.0 & 1.1 & 0.7 & 147 & 214 & 151 & 18 \\
\hline \multicolumn{10}{|l|}{ DAT $^{\mathrm{x}}$} \\
\hline 28 & $\mathrm{NI}^{\mathrm{w}}$ & $0.80 \mathrm{~b}$ & 4.1 & $0.8 \mathrm{c}$ & 0.6 & 129 & $164 \mathrm{c}$ & $96 \mathrm{~d}$ & $15 \mathrm{~b}$ \\
\hline 42 & $7.0 \mathrm{a}$ & $0.87 \mathrm{a}$ & 4.6 & $1.0 \mathrm{~b}$ & 0.6 & 145 & $280 \mathrm{a}$ & $246 \mathrm{a}$ & $33 \mathrm{a}$ \\
\hline 56 & $5.8 \mathrm{~b}$ & $0.61 \mathrm{c}$ & 4.3 & $1.2 \mathrm{a}$ & 0.6 & 121 & $187 \mathrm{bc}$ & $181 \mathrm{~b}$ & $11 \mathrm{~b}$ \\
\hline 70 & $6.1 \mathrm{~b}$ & $0.63 \mathrm{c}$ & 4.1 & $1.2 \mathrm{a}$ & 0.7 & 125 & $197 \mathrm{~b}$ & $144 \mathrm{c}$ & $17 \mathrm{~b}$ \\
\hline \multicolumn{10}{|l|}{$P$} \\
\hline
\end{tabular}

${ }^{2}$ Means followed by the same letter within each factor in a column are not significantly different based on Fisher's protected least significant difference test at $95 \%$ confidence.

yPlastic mulches were black ("black"; PlastiTech, Saint-Remi, Québec, Canada), black with a 10-cm wide silver strip ("black with silver strip"; Intergro, Safety Harbor, FL), silver on black ("silver1"; Clarke, Ag Plastics, Greenwood, VA), silver on black ("silver2"; RepelGro; ReflecTek Foils, Inc., Lake Zurich, IL), silver on black with a 10-cm wide black strip along the central portion of the film ("silver with black strip"; RepelGro, Reflectek), white ("white1"; PlastiTech), white-on-black ("white2"; PlastiTech), and white on black with a silver 10-cm wide silver strip ("white with silver strip"; Intergro). All mulches were made out of low-density polyethylene, $1.52 \mathrm{~m}$ wide, $25 \mu \mathrm{m}$ thick, and their surface texture was slick.

${ }^{\times}$The data for days after transplanting (DAT) are a composite for all mulches.

${ }^{\text {w}}$ Data not included (NI). The nitrogen values at this sampling data were suspiciously high (mean $=17.4 \%$ ), suggesting the possibility of errors in the measurement. 


\begin{tabular}{|c|c|c|c|c|c|c|c|c|c|}
\hline \multirow[b]{3}{*}{$\operatorname{Mulch}(\mathrm{M})^{\mathrm{y}}$} & \multicolumn{9}{|c|}{ Nutrient concn } \\
\hline & Nitrogen & Phosphorus & Potassium & Calcium & Magnesium & Manganese & Iron & Zinc & Copper \\
\hline & \multicolumn{5}{|c|}{$(\%)$} & \multicolumn{4}{|c|}{$\left(\mathrm{mg} \cdot \mathrm{kg}^{-1}\right)$} \\
\hline Black & 3.7 & 0.41 & 5.2 & 0.44 & 0.36 & 28 & 106 & 54 & 17 \\
\hline Black with silver strip & 3.4 & 0.26 & 5.2 & 0.31 & 0.30 & 20 & 103 & 54 & 18 \\
\hline Silver1 & 3.5 & 0.20 & 4.8 & 0.24 & 0.30 & 15 & 101 & 57 & 16 \\
\hline Silver2 & 3.7 & 0.11 & 5.2 & 0.36 & 0.32 & 23 & 111 & 60 & 17 \\
\hline Silver with black strip & 3.5 & 0.16 & 5.2 & 0.32 & 0.32 & 21 & 92 & 60 & 20 \\
\hline White1 & 3.8 & 0.13 & 5.0 & 0.29 & 0.29 & 16 & 155 & 68 & 20 \\
\hline White2 & 3.3 & 0.15 & 4.9 & 0.29 & 0.31 & 25 & 109 & 59 & 9 \\
\hline White with silver strip & 3.5 & 0.19 & 4.8 & 0.32 & 0.32 & 70 & 124 & 72 & 17 \\
\hline$P$ & 0.359 & 0.074 & 0.238 & 0.787 & 0.245 & 0.274 & 0.939 & 0.263 & 0.063 \\
\hline
\end{tabular}

${ }^{\mathrm{z}}$ Means followed by the same letter in a column are not significantly different based on Fisher's protected least significant difference test at $95 \%$ confidence.

yPlastic mulches were black ("black"; PlastiTech, Saint-Remi, Québec, Canada), black with a 10-cm wide silver strip ("black with silver strip"; Intergro, Safety Harbor, FL), silver on black ("silver1"; Clarke, Ag Plastics, Greenwood, VA), silver on black ("silver2”; RepelGro; ReflecTek Foils, Inc., Lake Zurich, IL), silver on black with a 10-cm wide black strip along the central portion of the film ("silver with black strip"; RepelGro, Reflectek), white ("white1"; PlastiTech), white-on-black ("white2"; PlastiTech), and white on black with a silver 10-cm wide silver strip ("white with silver strip"; Intergro). All mulches were made out of low-density polyethylene, $1.52 \mathrm{~m}$ wide, $25 \mu \mathrm{m}$ thick, and their surface texture was slick.

Table 6. Leaf nutrient concentrations in bell pepper as affected by plastic mulch color and days after transplanting. Tifton, GA, Spring of 2003. ${ }^{2}$

\begin{tabular}{|c|c|c|c|c|c|c|c|c|c|}
\hline \multirow[b]{3}{*}{$\operatorname{Mulch}(\mathrm{M})^{\mathrm{y}}$} & \multicolumn{9}{|c|}{ Nutrient concn } \\
\hline & Nitrogen & Phosphorus & Potassium & Calcium & Magnesium & Manganese & Iron & Zinc & Copper \\
\hline & \multicolumn{5}{|c|}{$(\%)$} & \multicolumn{4}{|c|}{$\left(\mathrm{mg} \cdot \mathrm{kg}^{-1}\right)$} \\
\hline Black & $7.5 \mathrm{a}$ & $0.60 \mathrm{ab}$ & $3.6 \mathrm{~b}$ & $1.8 \mathrm{e}$ & $0.65 \mathrm{ab}$ & $89 a$ & $149 \mathrm{abc}$ & $84 \mathrm{ab}$ & $8 \mathrm{~d}$ \\
\hline $\begin{array}{l}\text { Black with silver } \\
\text { strip }\end{array}$ & $6.4 \mathrm{~cd}$ & $0.61 \mathrm{a}$ & $3.7 \mathrm{~b}$ & $2.3 \mathrm{~d}$ & $0.57 \mathrm{~b}$ & $87 \mathrm{a}$ & $167 \mathrm{a}$ & $80 \mathrm{~b}$ & $8 \mathrm{~d}$ \\
\hline Silver1 & $6.4 \mathrm{~cd}$ & $0.55 \mathrm{bc}$ & $3.4 \mathrm{~b}$ & $3.4 \mathrm{~b}$ & $0.67 \mathrm{ab}$ & $76 \mathrm{~b}$ & $128 \mathrm{c}$ & $69 \mathrm{~d}$ & $9 \mathrm{~cd}$ \\
\hline Silver2 & $6.3 \mathrm{~d}$ & $0.56 \mathrm{abc}$ & $3.6 \mathrm{~b}$ & $4.3 \mathrm{a}$ & $0.74 \mathrm{a}$ & $91 \mathrm{a}$ & $153 \mathrm{ab}$ & $77 \mathrm{bc}$ & $12 \mathrm{c}$ \\
\hline $\begin{array}{l}\text { Silver with black } \\
\text { strip }\end{array}$ & $6.7 \mathrm{bc}$ & $0.59 \mathrm{ab}$ & $3.6 \mathrm{~b}$ & $2.8 \mathrm{c}$ & $0.67 \mathrm{ab}$ & 89 a & $140 \mathrm{bc}$ & $72 \mathrm{~cd}$ & $10 \mathrm{~cd}$ \\
\hline White1 & $6.5 \mathrm{~cd}$ & $0.53 \mathrm{c}$ & $4.3 \mathrm{a}$ & $1.7 \mathrm{e}$ & $0.71 \mathrm{a}$ & $84 \mathrm{ab}$ & $137 \mathrm{bc}$ & $83 \mathrm{ab}$ & $20 \mathrm{a}$ \\
\hline White2 & $6.9 \mathrm{~b}$ & $0.53 \mathrm{c}$ & $3.9 \mathrm{ab}$ & $1.9 \mathrm{e}$ & $0.67 \mathrm{ab}$ & $86 \mathrm{ab}$ & $130 \mathrm{c}$ & $83 \mathrm{ab}$ & $17 \mathrm{ab}$ \\
\hline $\begin{array}{l}\text { White with silver } \\
\text { strip }\end{array}$ & $7.0 \mathrm{~b}$ & $0.47 \mathrm{~d}$ & $3.7 \mathrm{~b}$ & $2.3 \mathrm{~d}$ & $0.71 \mathrm{a}$ & $90 \mathrm{a}$ & $128 \mathrm{c}$ & $88 \mathrm{a}$ & $15 \mathrm{~b}$ \\
\hline \multicolumn{10}{|l|}{$\mathrm{DAT}^{\mathrm{x}}$} \\
\hline 20 & $7.1 \mathrm{a}$ & $0.94 \mathrm{a}$ & $6.2 \mathrm{a}$ & $1.8 \mathrm{~b}$ & $0.88 \mathrm{a}$ & $87 \mathrm{~b}$ & $227 \mathrm{a}$ & $116 \mathrm{a}$ & $19 \mathrm{a}$ \\
\hline 27 & $\mathrm{ND}^{\mathrm{v}}$ & $0.72 \mathrm{~b}$ & $5.7 \mathrm{~b}$ & $7.4 \mathrm{a}$ & $0.95 \mathrm{a}$ & $118 \mathrm{a}$ & $152 \mathrm{~b}$ & $63 \mathrm{~d}$ & $13 \mathrm{~b}$ \\
\hline 33 & $6.3 \mathrm{~b}$ & $0.49 \mathrm{c}$ & $1.2 \mathrm{~d}$ & $0.8 \mathrm{~d}$ & $0.47 \mathrm{c}$ & $94 \mathrm{~b}$ & $122 \mathrm{c}$ & $84 \mathrm{~b}$ & $5 \mathrm{~d}$ \\
\hline 48 & $\mathrm{ND}^{\mathrm{v}}$ & $0.34 \mathrm{~d}$ & $2.6 \mathrm{c}$ & $1.4 \mathrm{c}$ & $0.43 \mathrm{c}$ & $61 \mathrm{~d}$ & $101 \mathrm{~d}$ & $70 \mathrm{c}$ & $9 \mathrm{c}$ \\
\hline 61 & $\mathrm{ND}^{\mathrm{v}}$ & $0.29 \mathrm{e}$ & $2.8 \mathrm{c}$ & $1.4 \mathrm{c}$ & $0.63 \mathrm{~b}$ & $72 \mathrm{c}$ & $105 \mathrm{~cd}$ & $66 \mathrm{~cd}$ & $15 \mathrm{~b}$ \\
\hline \multicolumn{10}{|l|}{$P$} \\
\hline Mulch & $<0.001$ & $<0.001$ & 0.058 & $<0.001$ & 0.084 & 0.087 & 0.005 & $<0.001$ & $<0.001$ \\
\hline DAT & $<0.001$ & $<0.001$ & $<0.001$ & $<0.001$ & $<0.001$ & $<0.001$ & $<0.001$ & $<0.001$ & $<0.001$ \\
\hline $\mathrm{M} \times \mathrm{DAT}$ & $<0.001$ & 0.022 & 0.405 & $<0.001$ & 0.091 & 0.869 & 0.009 & 0.046 & $<0.001$ \\
\hline
\end{tabular}

${ }^{\mathrm{z}}$ Means followed by the same letter within each factor in a column are not significantly different based on Fisher's protected least significant difference test at $95 \%$ confidence.

yPlastic mulches were black ("black"; PlastiTech, Saint-Remi, Québec, Canada), black with a 10-cm wide silver strip ("black with silver strip"; Intergro, Safety Harbor, FL), silver on black (“silver1"; Clarke, Ag Plastics, Greenwood, VA), silver on black (“silver2”; RepelGro; ReflecTek Foils, Inc., Lake Zurich, IL), silver on black with a 10-cm wide black strip along the central portion of the film ("silver with black strip"; RepelGro, Reflectek), white ("white1"; PlastiTech), white-on-black ("white2"; PlastiTech), and white on black with a silver 10-cm wide silver strip ("white with silver strip"; Intergro). All mulches were made out of low-density polyethylene, $1.52 \mathrm{~m}$ wide, $25 \mu \mathrm{m}$ thick, and their surface texture was slick.

${ }^{x}$ The data for days after transplanting (DAT) are a composite for all mulches.

${ }^{w}$ Data not included. The nitrogen values at this sampling data were suspiciously high (mean $=17.4 \%$ ), suggesting the possibility of errors in the measurement. vata not determined (ND).

were not low enough to reduce maximum fruit yield by greater than $10 \%$. Thus, $25{ }^{\circ} \mathrm{C}$ or less was chosen as a lower point of the optimal range, which corresponds to the lowest mean RZT (seasonal or for the first 28 DAT). Then, the optimal ranges of RZT were 26 to $27.6{ }^{\circ} \mathrm{C}$ or less (calculated from the mean seasonal RZTs) and 25 to $27.3^{\circ} \mathrm{C}$ or less (calculated from the mean RZTs for the first 42 DAT). Using an average of the two estimates, the optimal range of RZT for bell pepper fruit yield was computed to be 25 to $27.5^{\circ} \mathrm{C}$ or less.

Fruit number did not respond to changes in mean RZT for the season in the spring but declined quadratically with increasing RZTs in the fall $\left(\mathrm{y}=-3.29 \mathrm{x}^{2}+184 \times-2579.3 ; R^{2}=\right.$ $0.68 ; P=0.059)$.

In both seasons, total number of fruit was much larger than the number of marketable fruit because bell pepper plants had a large number of cull fruit, which included immature green fruit as well as fruit with decay and physiological disorders.

\section{Discussion}

Root zone temperature and reflected photosynthetically active radiation. Plastic film mulches alter the energy balance around the crop and thus modify root zone temper- ature (Ham et al., 1993; Lamont, 2005; Liakatas et al., 1986; Tarara, 2000). The effect of plastic mulches on energy balance, RZT, and light reflected from the mulch is associated with mulch optical properties of transmittance, absorbance, and reflectance of both short wave $(0.3$ to $1.1 \mu \mathrm{m}$, ultraviolet and visible light) and long wave (2.5 to $25 \mu \mathrm{m}$, infrared). Results of this study are consistent with reports indicating that black mulches have higher RZTs compared with white or silver mulches (Lamont, 2005; Tarara, 2000). The finding that silver mulches showed reduced RZTs and the smallest diurnal fluctuation is also consistent with previous reports in tomato (Díaz-Pérez 
Table 7. Fruit nutrient concentrations in bell pepper grown on colored plastic film mulches, Tifton, GA, Spring of $2003 .{ }^{2}$

\begin{tabular}{|c|c|c|c|c|c|c|c|c|c|}
\hline \multirow{2}{*}{$\operatorname{Mulch}(\mathrm{M})^{\mathrm{y}}$} & \multicolumn{9}{|c|}{ Nutrient concn } \\
\hline & Nitrogen & Phosphorus & Potassium & Calcium & Magnesium & Manganese & Iron & Zinc & Copper \\
\hline Black & $\mathrm{ND}^{\mathrm{x}}$ & 0.35 & 2.3 & $0.27 \mathrm{~b}$ & 0.19 & $26 \mathrm{c}$ & 90 & $53 \mathrm{c}$ & $7 \mathrm{c}$ \\
\hline Silver1 & ND & 0.39 & 2.3 & $0.26 \mathrm{~b}$ & 0.20 & $27 \mathrm{bc}$ & 95 & $56 \mathrm{abc}$ & $12 \mathrm{a}$ \\
\hline Silver2 & ND & 0.38 & 2.3 & $0.24 \mathrm{~b}$ & 0.20 & $27 \mathrm{bc}$ & 85 & $57 \mathrm{abc}$ & $13 \mathrm{a}$ \\
\hline Silver with black strip & ND & 0.35 & 2.5 & $0.24 \mathrm{~b}$ & 0.20 & $32 \mathrm{a}$ & 92 & $60 \mathrm{ab}$ & $12 \mathrm{a}$ \\
\hline White1 & ND & 0.29 & 2.3 & $0.21 \mathrm{~b}$ & 0.19 & $27 \mathrm{bc}$ & 77 & $53 \mathrm{c}$ & $10 \mathrm{ab}$ \\
\hline$P$ & & 0.519 & 0.317 & 0.016 & 0.923 & 0.020 & 0.443 & 0.020 & 0.037 \\
\hline
\end{tabular}

${ }^{\mathrm{z}}$ Means followed by the same letter in a column are not significantly different based on Fisher's protected least significant difference test at $95 \%$ confidence.

yPlastic mulches were black ("black"; PlastiTech, Saint-Remi, Québec, Canada), black with a 10-cm wide silver strip ("black with silver strip"; Intergro, Safety Harbor, FL), silver on black ("silver1"; Clarke, Ag Plastics, Greenwood, VA), silver on black ("silver2"; RepelGro; ReflecTek Foils, Inc., Lake Zurich, IL), silver on black with a 10-cm wide black strip along the central portion of the film ("silver with black strip"; RepelGro, Reflectek), white ("white1"; PlastiTech), white-on-black ("white2"; PlastiTech), and white on black with a silver 10-cm wide silver strip ("white with silver strip"; Intergro). All mulches were made out of low-density polyethylene, $1.52 \mathrm{~m}$ wide, $25 \mu \mathrm{m}$ thick, and their surface texture was slick.

${ }^{\mathrm{x}}$ Data not determined (ND).

Table 8. Fruit yields of bell pepper plants grown on colored plastic film mulches, Tifton, GA, Fall of 2002 and Spring of $2003 .^{\text {z }}$

\begin{tabular}{|c|c|c|c|c|c|c|c|c|}
\hline \multirow{2}{*}{ Mulch $^{y}$} & \multicolumn{4}{|c|}{ Fall 2002} & \multicolumn{4}{|c|}{ Spring 2003} \\
\hline & \multicolumn{2}{|c|}{ Marketable yield $^{\mathrm{x}}$} & \multicolumn{2}{|c|}{ Total yield ${ }^{\mathrm{w}}$} & \multicolumn{2}{|c|}{ Marketable yield ${ }^{\mathrm{x}}$} & \multicolumn{2}{|c|}{ Total yield ${ }^{\mathrm{w}}$} \\
\hline Black & $1.7 \mathrm{bc}$ & $0.28 \mathrm{bc}$ & $7.5 \mathrm{bc}$ & $0.57 \mathrm{bc}$ & $2.6 \mathrm{ab}$ & $0.47 \mathrm{ab}$ & $6.7 \mathrm{c}$ & $1.01 \mathrm{ab}$ \\
\hline Silver1 & $3.1 \mathrm{a}$ & $0.52 \mathrm{a}$ & $10.4 \mathrm{ab}$ & $0.83 \mathrm{a}$ & $2.2 \mathrm{~b}$ & $0.33 \mathrm{~b}$ & $7.6 \mathrm{ab}$ & $0.88 \mathrm{~b}$ \\
\hline Silver2 & $2.8 \mathrm{ab}$ & $0.49 \mathrm{ab}$ & $10.1 \mathrm{abc}$ & $0.83 \mathrm{a}$ & $2.6 \mathrm{ab}$ & $0.40 \mathrm{ab}$ & $8.0 \mathrm{a}$ & $0.99 \mathrm{ab}$ \\
\hline Silver with black strip & $2.3 \mathrm{ab}$ & $0.37 \mathrm{abc}$ & $11.4 \mathrm{a}$ & $0.79 \mathrm{ab}$ & $3.4 \mathrm{a}$ & $0.53 \mathrm{a}$ & $7.8 \mathrm{ab}$ & $1.07 \mathrm{a}$ \\
\hline White1 & $1.8 \mathrm{bc}$ & $0.28 \mathrm{bc}$ & $9.3 \mathrm{abc}$ & $0.62 \mathrm{abc}$ & $2.3 \mathrm{ab}$ & $0.35 \mathrm{ab}$ & $6.6 \mathrm{c}$ & $0.84 \mathrm{~b}$ \\
\hline$P$ & 0.008 & 0.007 & 0.036 & 0.002 & 0.442 & 0.274 & 0.033 & 0.152 \\
\hline
\end{tabular}

${ }^{\mathrm{z}}$ Means followed by the same letter in a column are not significantly different based on Fisher's protected least significant difference test at $95 \%$ confidence.

yPlastic mulches were black ("black"; PlastiTech, Saint-Remi, Québec, Canada), black with a 10-cm wide silver strip ("black with silver strip"; Intergro, Safety Harbor, FL), silver on black ("silver1"; Clarke, Ag Plastics, Greenwood, VA), silver on black ("silver2"; RepelGro; ReflecTek Foils, Inc., Lake Zurich, IL), silver on black with a 10-cm wide black strip along the central portion of the film ("silver with black strip"; RepelGro, Reflectek), white ("white1"; PlastiTech), white-on-black ("white2"; PlastiTech), and white on black with a silver 10-cm wide silver strip ("white with silver strip"; Intergro). All mulches were made out of low-density polyethylene, $1.52 \mathrm{~m}$ wide, $25 \mu \mathrm{m}$ thick, and their surface texture was slick.

${ }^{x}$ Included only mature green fruit.

wincluded both immature and mature green fruit.
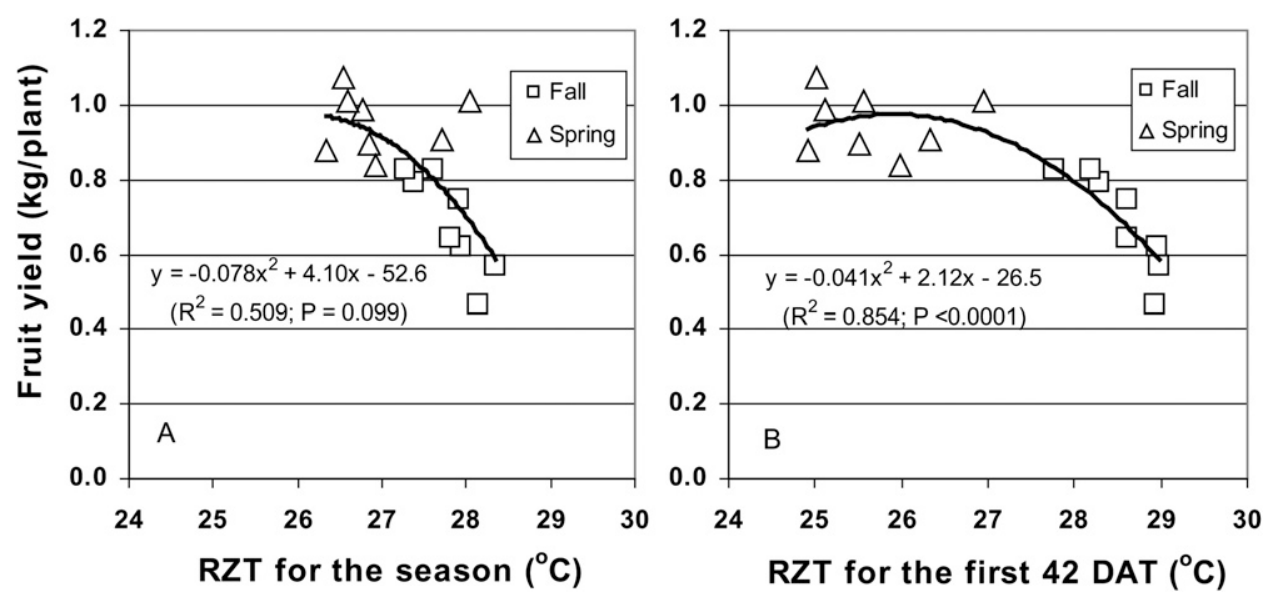

Fig. 4. Fruit yield of bell pepper plants as a function of mean root temperature during the entire season (A) and during the first $42 \mathrm{~d}$ after transplanting (B). Bell pepper plants were grown on various colored plastic film mulch treatments; Tifton, GA, Fall of 2002 and Spring of 2003. Each point represents the mean of four replications for each plastic mulch treatment.

and Batal, 2002) and tomatillo (Díaz-Pérez et al., 2005).

The percentage of $P A R$ reflected from the surface of the film mulch was negatively related with RZT under mulch (Fig. 1), consistent with previous reports showing high RZTs under mulches (e.g., black mulch) with reduced percentage of reflection of $P A R$ (Díaz-Pérez and Batal, 2002; Díaz-Pérez et al., 2005).

The combination of two different mulch colors on the same mulch surface may affect the optical or thermal properties of the film as shown by the increased $P A R$ reflection and reduced RZT in black mulch having a silver strip in the central portion of the film. Interestingly, the presence of a black strip on silver mulch resulted in decreased RZT, rather than increased, as would be expected by the higher ability of black mulch of absorbing more incoming infrared radiation 
compared with silver mulch. Possibly, the black strip allowed for a higher loss of infrared radiation during the night. Previous studies have shown that silver mulches retain more heat during the night resulting in higher nighttime values of RZT and less diurnal fluctuations in RZT compared with other plastic film mulches (Díaz-Pérez, 2009; Díaz-Pérez et al., 2005).

Thrips and Tomato spotted wilt. Thrips is an important insect pest in bell pepper because of its ability to transmit the virus that causes TSW, a disease that causes serious damage to bell pepper and tomato in several areas of the world, including the southeast United States (Zitter et al., 1991). The strategies to control TSW have included the use of silver mulches intended to reduce thrips activity (Abou-Jawdah et al., 2000; Greenough and Black, 1990; Momol et al., 2004). In this study, the finding that the number of thrips per flower was unaffected by mulch treatment and not related to the amount of light reflected from the mulches contrasts with other studies showing that silver reflective mulches, by reflecting ultraviolet light, reduce the populations of flower thrips and other insect vectors (Csizinszky et al., 1995; Olson et al., 2000; Schalk et al., 1979; Schalk and Robbins, 1987). Thus, the data suggest that the mechanism through which silver mulches influence thrips behavior and transmission of TSW may be not fully understood. In tomato, use of plastic mulches that created conditions of high RZT stress resulted in reduced plant growth and yield and predisposed the plants to earlier expression of TSW symptoms compared with plants grown at RZTs more favorable to tomato plant growth (Díaz-Pérez et al., 2007).

Soil water status. Over the last decades, vegetable growers have used plastic film mulches to warm the soil, reduce weeds, and conserve soil moisture (Lamont, 1993; Zhang et al., 2008). Because of the high heat capacity of water, soil moisture affects soil temperature with soil temperature decreasing with increasing soil water status. However, the effect of plastic film mulch color on soil water status is far from understood. In this study, mulch color was not consistently related to soil water status (soil water content and soil water potential), and there was no relationship between soil water status and RZT under mulch. This may be because all plastic mulches used had similar thicknesses and were made of low-density polyethylene, thus probably having similar water vapor transfer properties.

Plant growth, gas exchange, and plant mineral nutrients. Root zone temperature affects the growth and the physiological activities in plants. During bell pepper plant establishment, occurrence of low RZTs (infraoptimal RZTs) may limit plant growth, whereas presence of high RZTs (supraoptimal RZTs) may also inhibit plant growth. Numerous studies report on the beneficial effect of mulches on soil warming resulting in increased plant growth early in the spring season (Farias-Larios and Orozco-Santos, 1997;
Lamont, 1993, 2005; Rubeiz and Freiwat, 1995; Tarara, 2000). In this study, plant growth was not determined in the spring. However, in the fall, vegetative growth decreased with increasing RZTs, suggesting that heat stress was the cause of growth reduction in bell pepper plants. Similarly, in tomato and tomatillo grown in Tifton, GA, like in this study, the use of dark mulches produced high RZTs resulting in reduced plant vegetative growth during the fall season.

Despite the effects of RZT on plant growth, gas exchange and leaf and fruit mineral nutrient concentrations were not associated with plastic mulches and RZT. These results contrast with studies in other crops that show that RZT influences both gas exchange and the concentration of foliar mineral nutrients. In tomato grown in solution culture at various RZTs, nutrient uptake for essential elements peaked at $26.7{ }^{\circ} \mathrm{C}$ (Tindall et al., 1990), whereas in potato grown on colored mulches, differences in RZT were associated with differences in the concentrations of copper and zinc in the leaves and the tubers (Baghour et al., 2002). In tomato (Lycopersicon esculentum Mill. cv. Vendor), an increase in RZT from 12 to $24{ }^{\circ} \mathrm{C}$ increased $\mathrm{P}, \mathrm{K}$, magnesium, calcium, iron, and manganese content of leaves but had the opposite effect on $\mathrm{Na}$ (Gosselin and Trudel, 1983).

Plastic mulches may affect bell pepper plant growth and fruit yield by factors other than RZT. In a study in South Carolina, mulch surface color was reported to affect the growth of bell pepper plants and the amount and quality of upwardly reflected light. The authors proposed that bell pepper plant growth is affected by relatively small changes in light environment (far-red:red ratio) induced by the surface color of the mulch (Decoteau et al., 1990).

The effect of light quality on bell pepper plants was not evaluated in this study. It is then not possible to know whether the different plant responses to plastic mulches in the spring and the fall are related to the percentage of light reflected from each the mulches. The percentage of light reflection from the mulch is primarily determined by the optical properties of the plastic mulch (Ham et al., 1993). The total irradiance differed among seasons $\left[14.5 \mathrm{MJ} \cdot \mathrm{m}^{-2}\right.$ (fall) and $22.2 \mathrm{MJ} \cdot \mathrm{m}^{-2}$ (spring)] and may explain, at least partially, the occurrence of lower yields in the fall than in the spring.

Soil moisture is another factor that significantly affects plant growth. However, soil moisture probably played no significant role to explain plant growth in this study because there was no relationship $(P \leq 0.05)$ between plant growth with either soil water content or soil water potential.

Fruit yield. Fruit yields were low in both fall and spring seasons. Marketable and total yields were 5,227 and $9,992 \mathrm{~kg} \cdot \mathrm{ha}^{-1}$ in the fall and 6,026 and 13,794 kg.ha ${ }^{-1}$ in the spring. In Georgia, the average bell pepper marketable yield in 2002 and 2003 was 22,400 $\mathrm{kg} \cdot \mathrm{ha}^{-1}$ (USDA, 2009). Fruit yields were low proba- bly because of high insect and disease pressures and low temperatures late in the fall season and a short harvesting season in both seasons.

RZT is an important factor in plant growth and yield of vegetable crops (Cooper, 1973). In this study, plastic mulch influenced bell pepper fruit yield, although yield responses in the fall were different from those in the spring. In several crops grown in areas with cool spring conditions, the use of plastic mulches (e.g., black) with a high soil-warming ability has been found to increase yield (Ibarra et al., 2001; Lamont, 1993). In a study conducted in Maine, bell pepper plants on either black mulch with a white strip or on silver mulch produced significantly greater yields than plants on black plastic mulch with no white strip (Hutton and Handley, 2007).

The literature is often conflicting with respect to the effects of plastic mulch color on plant growth and yield of vegetable crops. This lack of consistency in the responses is probably the result of environmental differences caused by geographical location or season. Additionally, many reports do not include information about the environmental conditions (e.g., air temperature and RZT) during the study, making the comparison of results among studies difficult. There are few reports evaluating the same plastic mulches in different seasons (e.g., spring and fall) and thus under contrasting environmental conditions (Díaz-Pérez, 2009; Díaz-Pérez and Batal, 2002), as we did in this study. The evaluation of the impacts of plastic mulches under a wider range of air and soil temperatures provides more complete information on the crop responses to RZT and other environmental factors.

In the fall, both marketable and total yields decreased with increasing mean seasonal RZT, whereas in the spring, the yield differences were not related to RZT. Our results showed that the optimal range in RZT of bell pepper fruit yield ( 25 to $27.5{ }^{\circ} \mathrm{C}$ or less) is similar to the optimal RZT of tomato $\left(26.3{ }^{\circ} \mathrm{C}\right.$ ) and tomatillo (Physalis ixocarpa Brot. ex Hornem) $\left(27.3^{\circ} \mathrm{C}\right)$, another solanaceous species (Díaz-Pérez and Batal, 2002; Díaz-Pérez et al., 2005). The similarity in the thermal responses of bell pepper, tomato, and tomatillo is not surprising considering that these crops are often grown under analogous climatic conditions. The calculated optimal range in RZT of this study for bell pepper yield is consistent with the optimal air temperature $\left(20\right.$ to $25^{\circ} \mathrm{C}$ ) for pepper plants (Wien, 1997), although it differs from the optimal RZT $\left(30^{\circ} \mathrm{C}\right)$ for bell pepper yield in a study under greenhouse conditions (Gosselin and Trudel, 1986).

Fruit yield was more related to RZT during the first 42 DAT $\left(r^{2}=0.854\right)$ than to seasonal RZT $\left(r^{2}=0.509\right)$. This is probably because RZTs tend to be similar among plastic mulches once the plants reach full canopy cover, which under the conditions of this study occurred at $\approx 42$ DAT. In tomatillo with full canopy cover, it was found that RZTs are similar among colored mulches and 
that RZTs depend on air temperature (DíazPérez et al., 2005).

In conclusion, plastic film mulches significantly influenced the microenvironment, plant growth, and fruit yield of bell pepper plants, although these effects varied between seasons. The differences in plant growth and yield were significantly related to RZT. The reduced plant growth and fruit yields in black mulches during the fall were probably the result of the increased RZTs, and thus higher heat accumulation, that resulted in higher plant heat stress conditions compared with silver and white mulches. Fruit yield decreased with mean seasonal RZTs above $27.5{ }^{\circ} \mathrm{C}$. The optimal range of RZT for bell pepper fruit yield was computed to be 25 to $27.5^{\circ} \mathrm{C}$ or less.

\section{Literature Cited}

Abou-Jawdah, Y., H. Sobh, S. El-Zammar, A. Fayyad, and H. Lecoq. 2000. Incidence and management of virus diseases of cucurbits in Lebanon. Crop Prot. 19:217-224.

AOAC. 1990. Official methods of analysis. Assn. Off. Anal. Chem. Washington, D.C. p. 74.

Baghour, M., D.A. Moreno, G. Villora, I. LopezCantarero, J. Hernandez, N. Castilla, and L. Romero. 2002. Root-zone temperature influences the distribution of $\mathrm{Cu}$ and $\mathrm{Zn}$ in potatoplant organs. J. Agr. Food Chem. 50:140-146.

Bosland, P.W. 1992. Chiles: A diverse crop. HortTechnology 2:7-10.

Cooper, A.J. 1973. Root temperature and plant growth-A review. Commonwealth Agriculture Bureaux, Slough, UK.

Csizinszky, A.A., D.J. Schuster, and J.B. Kring. 1995. Color mulches influence yield and insect pest populations in tomatoes. J. Amer. Soc. Hort. Sci. 120:778-784.

Decoteau, D.R., M.J. Kasperbauer, and P.G. Hunt. 1990. Bell pepper plant development over mulches of diverse colors. HortScience 25: 460-462.

Díaz-Pérez, J.C. 2009. Root zone temperature, plant growth and yield of broccoli [Brassica oleracea (Plenck) var. italica] as affected by plastic film mulches. Sci. Hort. 123:156-163.

Díaz-Pérez, J.C. and K.D. Batal. 2002. Colored plastic film mulches affect tomato growth and yield via changes in root-zone temperature. J. Amer. Soc. Hort. Sci. 127:127-135.

Díaz-Pérez, J.C., R. Gitaitis, and B. Mandal. 2007. Effects of plastic mulches on root zone temperature and on the manifestation of tomato spotted wilt symptoms and yield of tomato. Sci. Hort. 114:90-95.

Díaz-Pérez, J.C., S.C. Phatak, D. Giddings, D. Bertrand, and H.A. Mills. 2005. Root zone temperature, plant growth, and fruit yield of tomatillo as affected by plastic film mulch. HortScience 40:1312-1319.
Dodd, I.C., J. He, C.G.N. Turnbull, S.K. Lee, and C. Critchley. 2000. The influence of supraoptimal root-zone temperatures on growth and stomatal conductance in Capsicum annuиm $\mathrm{L}$. J. Expt. Bot. 51:239-248.

Farias-Larios, J. and M. Orozco-Santos. 1997. Color polyethylene mulches increase fruit quality and yield in watermelon and reduce insect pest populations in dry tropics. Gartenbauwissenschaft. 62:255-260.

Gosselin, A. and M.J. Trudel. 1983. Interactions between air and root temperatures on greenhouse tomato: II. Mineral composition of plants. J. Amer. Soc. Hort. Sci. 108:905-909.

Gosselin, A. and M.J. Trudel. 1986. Root-zone temperature effects on pepper. J. Amer. Soc. Hort. Sci. 111:220-224.

Gough, R.E. 2001. Color of plastic mulch affects lateral root development but not root system architecture in pepper. HortScience 36:66-68.

Greenough, D.R. and L.L. Black. 1990. Aluminumsurfaced mulch: An approach to the control of tomato spotted wilt virus in Solanaceous crops. Plant Dis. 74:805-808.

Ham, J.M., G.J. Kluitenberg, and W.J. Lamont 1993. Optical properties of plastic mulches affect the field temperature regime. J. Amer. Soc. Hort. Sci. 118:188-193.

Hutton, M.G. and D.T. Handley. 2007. Effects of silver reflective mulch, white inter-row mulch, and plant density on yields of pepper in Maine. HortTechnology 17:214-219.

Ibarra, L., J. Flores, and J.C. Díaz-Pérez. 2001. Growth and yield of muskmelon in response to plastic mulch and row covers. Sci. Hort. 87: 139-145.

Ibarra-Jimenez, L., J.M.F. Brondo, J.M. Lopez, S.A.R. Herrera, J.C. Diaz, J.L.H. Mendoza, and J.F. Larios. 2001. Growth analysis of muskmelon and bell pepper with mulch and rowcover. Revista Fitotecnia Mexicana 24:39-48.

Ibarra-Jimenez, L., R. Quezada-Martin, B. Cedeno-Rubalcava, A.J.D. Rio, and M. de la Rosa-Ibarra. 2006. Watermelon response to plastic mulch and row covers. Eur. J. Hort. Sci. 71:262-266.

Ibarra-Jimenez, L., A. Zermeno-Gonzalez, J. LozanoDel Rio, B. Cedeno-Rubalcava, and H. OrtegaOrtiz. 2008. Changes in soil temperature, yield and photosynthetic response of potato (Solanum tuberosum L.) under coloured plastic mulch. Agrochimica 52:263-272.

Krug, H. 1999. Vegetable production research in our time. Gartenbauwissenschaft. 64:97-100.

Lamont, J.W.J. 1993. Plastic mulches for the production of vegetable crops. HortTechnology 3 : $35-39$

Lamont, W.J. 2005. Plastics: Modifying the microclimate for the production of vegetable crops. HortTechnology 15:477-481.

Liakatas, A., J.A. Clark, and J.L. Monteith. 1986. Measurements of the heat-balance under plastic mulches. 1. Radiation balance and soil heatflux. Agr. For. Meteorol. 36:227-239.
Locascio, S.J., J.G.A. Fiskell, D.A. Graetz, and R.D. Hauck. 1985. Nitrogen accumulation by pepper as influenced by mulch and time of fertilizer application. J. Amer. Soc. Hort. Sci. 110:325-328.

Momol, M.T., S.M. Olson, J.E. Funderburk, J Stavisky, and J.J. Marois. 2004. Integrated management of tomato spotted wilt on field-grown tomatoes. Plant Dis. 88:882890.

Olson, S., J. Stavesky, T. Momol, and J. Funderburk. 2000. Reflective mulches and their effect on tomato yield and insect and disease management 31. Proc. Natl. Agric. Plastics Congr. 29: 605-609.

Rubatzky, V.E. and M. Yamaguchi. 1999. World vegetables: Principles, production, and nutritive values. Aspen Publishers, Inc., Gaithersburg, MD.

Rubeiz, I.G. and M.M. Freiwat. 1995. Rowcover and black plastic mulch effects on tomato production. Biol. Agr. Hort. 12:113-118.

Schalk, J.M., C.S. Creighton, R.L. Fery, W.R. Sitterly, B.W. Davis, T.L. McFadden, and A. Day. 1979. Reflective film mulches influence insect control and yield in vegetables. J. Amer. Soc. Hort. Sci. 104:759-762.

Schalk, J.M. and M.L. Robbins. 1987. Reflective mulches influence plant survival, production, and insect control in fall tomatoes. HortScience 22:30-32.

Tarara, J.M. 2000. Microclimate modification with plastic mulch. HortScience 35:169-180.

Tindall, J.A., H.A. Mills, and D.E. Radcliffe. 1990. The effect of root zone temperature on nutrient uptake of tomato. J. Plant Nutr. 13: 939-956.

U.S. Department of Agriculture. 2005. United States standards for grades of sweet bell pepper. U.S. Department of Agriculture, Agricultural Marketing Service. $<\mathrm{http}$ ://www.ams.usda. gov/AMSv1.0/getfile?dDocName=STELPRDC 5050318>.

U.S. Department of Agriculture. 2007. Vegetables and Melons Outlook/VGS-322/August 29. Economic Research Service. <http://www.ers. usda.gov/publications/vgs/2007/08Aug/VGS322. pdf $>$.

U.S. Department of Agriculture. 2009. Georgia Agricultural Facts. National Agricultural Statistics Service, Georgia Field Office, Athens, GA.

Wien, H.C. 1997. Peppers, p. 259-293. In: Wien, H.C. (ed.). The physiology of vegetable crops. $\mathrm{CAB}$ International, Ithaca, NY.

Zhang, Y.C., J.H. Han, and G.N. Kim. 2008. Biodegradable mulch film made of starchcoated paper and its effectiveness on temperature and moisture content of soil. Commun. Soil Sci. Plant Anal. 39:1026-1040.

Zitter, T.A., J.B. Jones, J.P. Jones, R.E. Stall, and T.A. Zitter. 1991. Tomato spotted wilt, p. 40 Compendium of tomato diseases. The American Phytopathological Society, St. Paul, MN. 